\title{
HOW TO MEASURE THE ECONOMIC INTEGRITY OF IBOR PANELS? A BEHAVIOURAL APPROACH
}

\author{
Piotr Mielus \\ SGH Warsaw School of Economics, Warsaw, Poland \\ e-mail: piotr.mielus@sgh.waw.pl \\ ORCID: 0000-0003-0194-5172 \\ (C) 2019 Piotr Mielus \\ This is an open access article distributed under the Creative Commons Attribution-NonCommercial- \\ -NoDerivs license (http://creativecommons.org/licenses/by-nc-nd/3.0/)
}

DOI: 10.15611/fins.2019.1.04

JEL Classification: G01, G14, G15

\begin{abstract}
Summary: IBOR manipulation imposed new benchmark regulations that forced the market to enter a path of the reform of the existing financial indices and the creation of new ones. The paper describes the evolution of two IBOR panels: one representing a global financial benchmark LIBOR, and the other representing a local PLN benchmark, WIBOR. The paper provides a quantitative analysis of partial quotes of IBOR panellists and suggests that economic integrity measures should be introduced for IBOR panels. The aim of the research is to define a set of tools that provide information regarding the efficiency of the process of the production of the interest rate benchmark. The research is supplemented with a behavioural analysis of the banks' decision-making process that interferes the contribution of IBOR data. The integrity measures can help market users and financial authorities in evaluating the quality of current and past panels and identifying behavioural factors impacting on partial quotes of the contributing banks.
\end{abstract}

Keywords: financial benchmarks, money market, behavioural finance.

\section{Introduction}

In the light of new European regulations, the benchmarks listed in the financial market formally became financial benchmarks, which are subject to special regulatory restrictions [EBA/ESMA 2013; IOSCO 2013; EP 2016]. The new regulations were created as a result of proven LIBOR and EURIBOR manipulations in order to improve the reliability of benchmarks published in the market and to protect benchmark users, including in particular consumers [Wheatley 2012; Abrantes-Metz et al. 2012; Hou, Skeie 2014; Ghandi et al. 2015]. The regulations apply to all benchmarks used between the regulated entities (funds and banks) and their customers. However, special attention is still paid to IBOR-type benchmarks, which, as originally assumed, represented the cost of money in the interbank market. 
The benchmarks play a crucial role for the economy, given the volume of instruments that are indexed thereunder (loans, bonds and derivatives). Thus, the benchmarks must be reformed very carefully in order to maintain the legal continuity of the existing benchmarks and not to disturb financial stability [Gradon 2013; Kirti 2017; Mielus 2017]. Regulators and market users should have tools aimed at assessing the reliability, stability and representativeness of the benchmarks [BIS 2013; MPG 2014; FSB 2014].

IBOR-type benchmarks were and still are calculated as the mean of quotes of panellists, i.e. those banks that contribute the data. For most benchmarks of this type, the data is based solely on the panellist's expert assessment. Thus, this is the price at which the bank can make the transaction. Such a methodology is contrary to the requirements of the new regulations, based on which the benchmarks must be firstly calculated on the grounds of the prices of the concluded transactions. Such an obligation results from the need to make the benchmark more representative (to reflect market realities) and more resistant to manipulation (in the case of the expert assessment, manipulation does not generate any cost for the panellist). The problem is that IBOR-type benchmarks represent a market that does not exist. After the financial crisis of 2007-2009, the structure of bank financing and the structure of turnover in the money market has changed.

Firstly, banks changed over to financing coming from the non-banking market, including in particular deposits placed by corporate and retail customers. This is caused by the increased credit risk of the banking sector and new liquidity regulations, which penalised interbank financing [Brousseau et al. 2013; Mielus, Mironczuk 2015]. Secondly, as a result of the rapid increase in credit risk and liquidity risk, unsecured time deposits in the wholesale market disappeared and were replaced with overnight deposits or secured (repo) deposits. Thus, IBOR benchmarks lost the transaction base on the grounds of which panellists calculated their partial quotes [Duffie, Stein 2015; Mielus 2016; Maciaszczyk 2018].

The article suggests measures which will enable us to estimate the degree of integrity of the published benchmarks. These measures are based on the history of partial quotes of banks which provide input data used to calculate the benchmarks. The distribution of the panellist's partial quotes may differ from the final distribution of the benchmark. The differences between the panellists' distributions indicate that the price generation procedures applied by individual banks are not consistent. The author tries to define the economic and behavioural reasons for these differences and analyses the volatility of these differences in time by dividing the analysed time series into research sub-periods. The purpose of this division is to separate the impact of the structural changes and the implemented regulations on the volatility of the panellists' price contribution. The analysis was made for the global market of USD LIBOR and the local market of PLN WIBOR.

The article consists of three parts. Part one describes the time series used in the analysis and defines the integrity measures that constitute the basis for the conclusions drawn below. Part two presents the interpretation of the results in 
terms of the impact of the behavioural factors on the decisions of the banks quoting the input data used to calculate the benchmarks. The final part of the article sums up the empirical results and presents the possible scenarios of further transformations in the financial benchmarks area.

\section{Analysis of panellists' quotes}

The analysis covers two money market benchmarks: USD LIBOR [IBA 2017] and WIBOR PLN [GPWB 2017]. For the former, three tenors were tested: 1M, 3M and $6 \mathrm{M}$ for the period from 25 March 1999 to 29 July 2016 (4389 observations). For the latter, six tenors were tested: $\mathrm{ON}, 1 \mathrm{~W}, 1 \mathrm{M}, 3 \mathrm{M}, 6 \mathrm{M}$ and $1 \mathrm{Y}$ for the period from 7 July 2009 to 8 November 2017 (2110 observations). The analysed data and timeframe were chosen on the basis of the relevant time series available in the Thomson Reuters database. The data were cleaned of observations which were found incorrect. ${ }^{1}$ For both IBOR benchmarks, information about fixing and partial quotes were collected. The data for USD LIBOR was available from 16 panellists, but only data for six banks referred to all tenors and all observation days. ${ }^{2}$ For PLN WIBOR, the data was collected from 11 panellists, but the series from seven banks were complete. ${ }^{3}$ For each of the nine price series, a distribution for fixing and distribution for partial quotes were tested for predefined sub-periods.

For USD LIBOR, the financial crisis of 2007-2008 and the regulatory changes initiated with the EBA/ESMA guidelines in 2013 were found to be a key event. Therefore, four sub-periods were distinguished:

1) before 9.08 .2007 , i.e. before the subprime crisis which destabilised the money market; ${ }^{4}$

2) between 9.08.2007 and 1.01.2009, a period when the financial crisis reached its zenith (heightened with the fall of Lehman Brothers on 15.09.2008);

3) between 1.01 .2009 and 6.06 .2013 , i.e. the day on which EBA/ESMA published principles providing for the first formal requirements for reformed benchmarks (the EU Regulation of 8.06.2016 was the final outcome of that process);

1 For example, a one-off change in a quote by one percentage point at the daily volatility of several basis points is an obvious error. The data supplier showed that the historic time series available for database subscribers were not cleaned of erroneous quotes.

2 The data for USD LIBOR is available for the following banks: Lloyds (100\%), Bank of Tokyo Mitsubishi (100\%), Barclays (100\%), Citibank (89\%), Rabobank (86\%), Credit Suisse (89\%), RBC (64\%), HSBC (100\%), Bank of America (89\%), Credit Agricole (32\%), Deutsche Bank (100\%), JPMorgan (56\%), Societe Generale (41\%), Norinchukin (49\%), RBS (100\%), UBS (83\%).

3 The data for PLN WIBOR is available for the following banks: BGK (100\%), BGŻ BNP (81\%), Bank Handlowy (84\%), Millennium (100\%), Pekao (100\%), BZ WBK (100\%), Deutsche Polska (31\%), ING Bank Śląski (100\%), mBank (100\%), PKO Bank Polski (100\%), Raiffeisen Polska (94\%).

${ }^{4}$ On 9.08.2007 BNP Paribas announced that it had stopped repurchasing shares of three of its investment funds connected with the subprime debt. Since then, the OIS-IBOR spread, which is a liquidity risk indicator, has expanded strongly. 
4) after 6.06.2013.

For PLN WIBOR, two events important for the money market were taken into account: the implementation of the new EU guidelines and related to that the amendments to local regulations on financial benchmarks in 2013, as well as the implementation of a bank tax in 2016, which had a great impact on interbank deposits. Thus, three sub-periods were distinguished:

1) before 1.07 .2013 , i.e. the enforcement date of amendments to the WIBOR rules, including the new regulatory environment [ACI 2013];

2) between 1.07.2013 and 1.01.2016, i.e. the period when the act on taxation on the banking sector's assets, which froze the money market for deposits whose term included the tax base calculation date, was passed;

3) after 1.01.2016.

Thirty sets (12 for LIBOR and 18 for WIBOR) were analysed in total for both fixings and 27 partial quotes. For each set, statistical measures describing the distribution characteristics on the fixing panels were determined.

Firstly, two measures of dispersion for banks' partial quotes were defined.

- Interquartile range of partial quotes

$$
I Q R=\frac{\sum_{1}^{n} I Q R_{t}}{N}, \text { where } I Q R_{t}=Q 3\left(X_{t}^{i}\right)-Q 1\left(X_{t}^{i}\right), \text { where } Q I-I \text { quartile }
$$

- Dispersion of minimum/maximum partial quotes

$$
D=\frac{\sum_{1}^{n} D_{t}}{N}, \text { where } D_{t}=\max \left(X_{t}^{i}\right)-\min \left(X_{t}^{i}\right)
$$

where: $X_{t}$ - IBOR fixing (for a given term) on the $t$ day; $X_{t}^{i}$ - IBOR quotation of the $i$ bank (for a given term) on the $t$ day

Secondly, measures of variances were developed to enable a comparison between the volatility of a fixing published, and the volatility of partial quotes:

- Daily standard deviation (for fixing and partial quotes)

$$
S D=\sqrt{\frac{\sum_{1}^{n}\left(d X_{t}-\overline{d X_{t}}\right)^{2}}{N}}, \text { where } d X_{t}=X_{t}-X_{t-1}
$$

- Average quotient of partial volatility and fixing volatility

$$
A V R=\frac{\sum_{1}^{n} \frac{S D^{i}}{S D}}{N}, \text { where } S D^{i}-\text { standard deviation for the } i \text { bank }
$$


- Quotient of maximum and minimum partial volatility

$$
Q V R=\frac{\max \left(S D^{i}\right)}{\min \left(S D^{i}\right)},
$$

Thirdly, the number of days without changes in the price was analysed:

- Share of zero changes (for fixing and partial quotes)

$$
Z C=\frac{N_{Z C}}{N},
$$

where $N_{Z C}=1$ if $d X_{t}=0$, where $N_{z c}$ - a quantity of zero daily changes

Fourthly, measures of partial quote deviation from the published fixing were introduced.

- Average absolute quote deviation from fixing

$$
A A E=\frac{\sum_{1}^{n}\left|d X_{t}^{i}-d X_{t}\right|}{N}
$$

- Range of absolute quote deviation from fixing

$$
A A R=\left(\min \left(A A E_{t}\right) ; \max \left(A A E_{t}\right)\right) .
$$

The results of the analyses are presented in attachments in a graphic form. In the next chapter, an attempt to interpret and present reasons for the results is made.

\section{Behavioural decision-making process}

Because of the non-transactional construction of the benchmarks, banks' quotations are fully based on the expert's judgment. Thus, fragmental input data given for benchmark fixing purposes stems solely from banks' individual decisions. Financial institutions aim at maximising their profit, on the one hand, and minimising their risk, on the other hand. For panellists, the latter prevails. In the present legal environment, the fear of being accused of manipulation and the risk of financial penalties limit the market factors used for rate quotation purposes ${ }^{5}$. This phenomenon is even stronger because the underlying market which IBOR theoretically refers to has lost its raison d'etre (except for the shortest maturities).

${ }^{5}$ The limitation of market factors for expert quotations is proven by the comparison of USD LIBOR volatility with the use of the new Waterfall method based on (if possible) transaction data. Data about the Waterfall test method was published on 17.03 .2018 by the IBA administrator. When data for USD for $1 \mathrm{M}, 3 \mathrm{M}$ and $6 \mathrm{M}$ are processed, the average difference of levels is $2 \mathrm{bp}$ and the volatility of semi-transaction rates is $64 \%$ greater than the volatility of purely expert rates. 
The regulatory changes mean that the risk connected with quotes based on the expert judgment has been increasing significantly. This risk results from the fact that quotes can be questioned, in good faith, by regulators and the regulated entities may be charged with financial penalties. Reputation issues (for institutions) and personal risk minimisation for natural persons that are responsible for the quotations for the IBOR panel at banks are also important. The new regulations introduce penal liability of persons accused of manipulating financial benchmarks. The increased risk of quotes is reflected by the decrease in dispersion and rate variance. Firstly, panellists try to show prices that are close to those of other panellists so as not to stand out in the analysed population. Secondly, panellists avoid changes in the rate because the new level must be economically justified, which may be questioned by the regulator.

The analysis of panellists' behaviour based on their partial quotes is based on the theory of herd behaviour [Shiller 1995] and thought contagions [Lynch 2000]. As proven by Avery and Zamksy [1999], behavioural coarsening as an element of herd behaviour results in discrepancies between market prices and an economic asset value. In the case of reference rates, the panellist environment minimises their risk by behavioural coarsening and quotes of individual banks neither differ nor increase the risk of investigation by regulators. Thought contagions, which are common among financial market players and result from the continuous exchange of information, in particular between market makers, are in favour of this process.

The results presented here indicate that only a segment of the panellist population tries to make the quotes consistent. This is proven by the increasing range of variances between the panellists. Among the quoting banks, there are banks that quote in an autoregressive way (i.e. inertly as regards their previous quotes and quotes of other panellists) and banks that quote on the grounds of a model based on exogenous variables (i.e. on the basis of their observation of other prices in the money market, which, because of their market nature, are naturally volatile). The former means that the volatility of the daily quotes of a given panellist is small. In turn, the latter is characterised by much greater variance than the variance of the published fixing.

At the same time, it must be taken into account that, given the construction of the benchmark calculation based on calculating a trimmed average, the quotes of banks that use the exogenous model are sometimes skipped in the benchmark calculation (as outliers). In effect, the volatility of the published benchmark is very small and determined by banks using the autoregressive model.

Nevertheless, the autoregressiveness of partial quotes manifests itself in the substantial share of zero daily changes for particular panellists. At the same time, this phenomenon does not need to contribute to the substantial number of zero changes in the published benchmark if the construction of the average calculation and the preciseness of the rate published (the number of decimal places) determine the series made of very small (but not zero) daily changes. Such a situation was observed for USD LIBOR after 2009. 
Table 1. Volatility of IBOR panel parameters in individual periods

\begin{tabular}{|c|c|c|c|c|c|c|c|}
\hline Benchmark & Period & $\begin{array}{c}\text { Economic and } \\
\text { legal conditions }\end{array}$ & Dispersion & $\begin{array}{c}\text { Benchmark } \\
\text { volatility }\end{array}$ & $\begin{array}{c}\text { Volatility } \\
\text { of partial } \\
\text { quotes }\end{array}$ & $\begin{array}{c}\text { Number of zero } \\
\text { observations }\end{array}$ & $\begin{array}{l}\text { Deviation of } \\
\text { partial quotes }\end{array}$ \\
\hline \multirow[t]{4}{*}{ LIBOR } & P1 & $\begin{array}{l}\text { Low credit } \\
\text { and liquidity } \\
\text { risk }\end{array}$ & Low & Medium & $\begin{array}{l}\text { Close to } \\
\text { fixing and } \\
\text { dispersed }\end{array}$ & $\begin{array}{l}\text { High for the } \\
\text { benchmark, } \\
\text { medium for } \\
\text { quotes }\end{array}$ & $\begin{array}{l}\text { Low and } \\
\text { convergent }\end{array}$ \\
\hline & P2 & $\begin{array}{l}\text { Financial } \\
\text { crisis }\end{array}$ & High & High & $\begin{array}{l}\text { Close to } \\
\text { fixing and } \\
\text { conver- } \\
\text { gent }\end{array}$ & $\begin{array}{l}\text { Low for the } \\
\text { benchmark } \\
\text { and quotes }\end{array}$ & $\begin{array}{l}\text { High and } \\
\text { dispersed }\end{array}$ \\
\hline & P3 & \begin{tabular}{|l} 
Post-crisis \\
environment \\
before the \\
implemen- \\
tation of the \\
regulation
\end{tabular} & High & Low & $\begin{array}{l}\text { Higher } \\
\text { than } \\
\text { fixing and } \\
\text { dispersed }\end{array}$ & $\begin{array}{l}\text { High for the } \\
\text { benchmark } \\
\text { and quotes }\end{array}$ & $\begin{array}{l}\text { High and } \\
\text { convergent }\end{array}$ \\
\hline & $\mathrm{P} 4$ & $\begin{array}{l}\text { Gradual im- } \\
\text { plementation } \\
\text { of regulations } \\
\text { on bench- } \\
\text { marks } \\
\end{array}$ & Medium & Low & $\begin{array}{l}\text { Higher } \\
\text { than } \\
\text { fixing and } \\
\text { dispersed }\end{array}$ & $\begin{array}{l}\text { Low for the } \\
\text { benchmark, } \\
\text { high for } \\
\text { quotes }\end{array}$ & $\begin{array}{l}\text { High and } \\
\text { convergent }\end{array}$ \\
\hline \multirow[t]{3}{*}{$\begin{array}{l}\text { WIBOR } \\
\text { (without } \\
\mathrm{O} / \mathrm{N} \text { ) }\end{array}$} & P1 & \begin{tabular}{|l|} 
Regulations \\
without chan- \\
ges in com- \\
parison with \\
the post-crisis \\
situation
\end{tabular} & High & High & $\begin{array}{l}\text { Close to } \\
\text { fixing and } \\
\text { conver- } \\
\text { gent }\end{array}$ & Low & \begin{tabular}{|l|} 
High and \\
dispersed
\end{tabular} \\
\hline & $\mathrm{P} 2$ & \begin{tabular}{|l|} 
Implemen- \\
tation of the \\
first regulato- \\
ry changes
\end{tabular} & Medium & Medium & $\begin{array}{l}\text { Close to } \\
\text { fixing and } \\
\text { conver- } \\
\text { gent }\end{array}$ & Medium & Medium \\
\hline & P3 & $\begin{array}{l}\text { Implemen- } \\
\text { tation of the } \\
\text { bank tax }\end{array}$ & Low & Low & $\begin{array}{l}\text { Higher } \\
\text { than } \\
\text { fixing and } \\
\text { dispersed }\end{array}$ & High & $\begin{array}{l}\text { Low and } \\
\text { convergent }\end{array}$ \\
\hline \multirow[t]{3}{*}{$\begin{array}{l}\text { WIBOR } \\
\mathrm{O} / \mathrm{N}\end{array}$} & P1 & \begin{tabular}{|l|} 
Regulations \\
without chan- \\
ges in com- \\
parison with \\
the post-crisis \\
situation
\end{tabular} & High & High & $\begin{array}{l}\text { Close to } \\
\text { fixing and } \\
\text { conver- } \\
\text { gent }\end{array}$ & Low & $\begin{array}{l}\text { High and } \\
\text { dispersed }\end{array}$ \\
\hline & P2 & \begin{tabular}{|l|} 
Implemen- \\
tation of the \\
first regulato- \\
ry changes \\
\end{tabular} & High & Medium & $\begin{array}{l}\text { Close to } \\
\text { fixing and } \\
\text { conver- } \\
\text { gent }\end{array}$ & Medium & $\begin{array}{l}\text { High and } \\
\text { dispersed }\end{array}$ \\
\hline & P3 & $\begin{array}{l}\text { Implemen- } \\
\text { tation of the } \\
\text { bank tax }\end{array}$ & High & Medium & $\begin{array}{l}\text { Close to } \\
\text { fixing and } \\
\text { conver- } \\
\text { gent }\end{array}$ & Medium & $\begin{array}{l}\text { High and } \\
\text { dispersed }\end{array}$ \\
\hline
\end{tabular}

Source: own elaboration. 
When analysing the statistical measures in detail, it must be considered which factors influenced the panellists' decisions in particular sub-periods. As a result of the volatility of the factors determining the panellists' behaviour, the time series for partial quotations differ. The changes in economic and legal factors that influence banks' decisions are summarised in Table 1.

The volatility of the panel's statistical parameters is dependent on the benchmark and the sub-period, as well as, in the case of WIBOR, on maturity (because of the separation of an overnight benchmark).

For LIBOR, the first analysed period covered time before the financial crisis and was characterised by low credit and liquidity the risks. The LIBOR panel was characterised by low dispersion (banks similarly assessed the cost of finance), average volatility (resulting from market conditions, because transactions on time deposits were liquid enough) and the relatively high number of zero benchmark changes with a much smaller number of zero changes in partial quotes (benchmark inertia resulted from the stable market environment and was stabilised with the benchmark construction where marginal quotes were rejected).

During the financial crisis, both quotes dispersion and benchmark volatility increased substantially. The number of zero variances dropped significantly and partial quotations were sometimes very far from the value of the benchmark and dispersed. This behaviour of banks may be explained by the unstable market situation and the increase in financial risks in the money market.

When the market calmed down after the crisis situation was mitigated, the benchmark volatility decreased. ${ }^{6}$ Initially, dispersion was high, but was reduced by the implementation of regulatory guidelines for benchmark input data. The greater volatility of partial quotes than of the benchmark with a large number of zero partial quotes $^{7}$ and the lack of extreme deviations of partial quotes from the benchmark were characteristic properties of that period.

Low dispersion and the dispersed surplus of quotes volatility results, on the one hand, from the construction of the benchmark as an average mean, but, on the other hand suggests that banks coming within the panel are diversified in terms of the quotation model they use. As described above, one group of banks quotes in an autoregressive way and replicates the volatility of the benchmark without deviating significantly from the benchmark fixing. In turn, the other group calculates partial prices on the basis of the model that takes into account exogenous factors and generates greater volatility (without increasing dispersion).

The time series for WIBOR, because of the shorter range of available data and other factors determining the situation in the money market, are divided into three

${ }^{6}$ The decrease in the benchmark volatility was connected not only with a drop in the credit risk, but mainly with the Fed's QE policy, which resulted in a strong drop and stabilisation in the yield curve at low levels because of a liquidity surplus generated by the open market operations of the central bank.

${ }^{7}$ The small number of zero quotes for the benchmark in the last sub-period (despite the substantial number of zero partial quotes) results from the benchmark construction, where the average mean is rounded to 5 decimal points. 
sub-periods. The first of the limiting dates of the sub-periods coincided with a LIBOR series (the implementation of preliminary regulations on best practices for benchmark contribution in the middle of 2013). The second date (beginning of 2016) resulted from a tax on banks' assets which was introduced in the Polish market and which burdens interbank deposits that pass the end of a month (the day on which a tax base is calculated).

As six different maturities were taken into account, an ON tenor was separated because of its different economic characteristics. Firstly, this is the only maturity which is strongly reflected in the transactions (the interbank deposit market is dominated by overnight transactions). Secondly, ON transactions, apart from the last business day of a month, are not subject to taxation. Consequently, the distribution of daily changes in $\mathrm{ON}$ fixing and partial quotes differs from other tenors.

For time deposits (longer than overnight), two prevailing phenomena can be observed:

1) the sharp drop in dispersion after the implementation of the new WIBOR rules in 2013;

2) the significant drop in variance after the enforcement of the tax on bank assets in 2016.

The reasons for these phenomena can be investigated by the use of behavioural analysis [Mielus 2018]. Firstly, it must be noted that the new rules were implemented as a consequence of the intervention of local regulators. Thus the regulated entities realised that WIBOR generation was monitored. Entities actively operating in the financial market modify their behaviour if they are aware of the fact that their actions are being observed. When the new regulations were implemented, the minimisation of the risk of being accused of manipulation became a key issue for banks contributing their data to the WIBOR panel. If there is no underlying market (the disappearance of interbank financing), partial quotes are generated practically solely on the basis of the panellist's expert judgement. The risk can be minimised through the maximum decrease in the factors differentiating the panellist's daily quotes from other quotes. In effect, all banks give almost identical prices as they are aware that quotes different than the average population could be treated as suspicious. This contributes to the sharp drop in partial quote dispersion.

Secondly, as a result of the implementation of the bank tax, transactions on interbank deposits passing through the tax base date, i.e. mainly longer than three weeks, were liquidated; and because of the final disappearance of the underlying market, WIBOR is no longer sensitive to natural market factors. Therefore the benchmark inertia, whose statistical effect is a material drop in the daily variances of changes, prevails. ${ }^{8}$ The banks perceive the disappearance of variances as a favourable effect, in terms of regulatory risk minimisation as well. Each change in

\footnotetext{
${ }^{8}$ In the year following the tax enforcement, the number of days without changes in benchmark levels for 3M WIBOR was $96 \%$.
} 
partial quotes must be based on market factors. If these factors disappear, the safest approach is to minimise the daily changes in quotes to the necessary extent.

At the same time, in the last analysed sub-period a new phenomenon, similar to the one observed for LIBOR fixing appeared: partial quotes for certain panellists reflected much greater variance than the published benchmark and the very variance for particular banks was strongly dispersed. This lets us distinguish two groups of banks in the WIBOR panel: banks that quote autoregressively (conservatively) by minimising the risk of their quotes standing out in fixing and the banks that calculate their quotes on the basis of the model, i.e. an internal algorithm including exogenous variables (e.g. the prices of other instruments in the money market). The latter generate greater variance, but in practice their quotations are usually treated by the fixing algorithm as marginal and are rejected during the calculation of an average mean. Thus, the banks whose quotes are based on the model have a limited impact on the level and volatility of the published benchmark (unless there are only few of them).

In turn, for the WIBOR ON benchmark, these phenomena did not exist because there was a underlying market and the benchmark was not used in legal agreements with consumers. ${ }^{9}$ Therefore the WIBOR ON series reflected the high dispersion and variance on a stable basis, which proves that the rate was strongly influenced by liquidity-related market factors.

\section{Conclusions}

As a result of the implementation of the new regulations on financial benchmarks, the manner the benchmarks are calculated by administrators should change. However, in the meantime, banks send their input data based on expert judgment, which should, theoretically speaking, rely on the prices of transactions made. As there are no liquid underlying markets, the expert judgement is not based on the market to a great extent, but is rather a function of the quotations of other panellists and the currently applicable regulations (the code of conduct).

As a result of the analysis of partial quotes on IBOR panels, we are able to identify the processes that influence prices in the money market. In the case of reference rates that are not based on concluded transactions, these processes are determined by panellists' decisions and not purely market factors. This is the case when the underlying market disappears (including unsecured time deposits in the interbank market) and banks that contribute their data are forced to use quotes based on expert judgments.

At the same time, we observe significant economic and regulatory changes in the financial market as a result of the crisis and the confirmed manipulation of IBOR-type rates during the crisis. The changes influence the behaviour of the banks

\footnotetext{
${ }^{9}$ For variable-rate loans, $3 \mathrm{M}$ WIBOR and 6M WIBOR are mostly used.
} 
contributing their data and behavioural factors have an unquestionable significance for money market benchmarks.

In the article, basic and newly established statistical measures were analysed to study the impact of the changes on the panellists' decision-making processes. The study was conducted separately for global USD LIBOR and local PLN WIBOR. For IBOR-type benchmarks, the non-transactional construction of the benchmark published has an impact on the distribution of the returns and characteristics of the panel data. The regulations penalise the publication of benchmarks based on expert judgment and generate legal and reputation risks for the entities contributing their data. In effect, panellist banks try to minimise the risks by implementing procedures aimed at making the quotation process more objective.

The developed quality measures allow the assessment of the integrity of benchmark panels as they provide information regarding the consistency of the partial quotes of the panellists. Moreover, this information reveals the quoting strategy of each analysed market maker and indirectly provides knowledge about the behavioural aspects of such strategies.

As the empirical data indicates, there are two types of such procedures: passive, where the model is based on the quotes of other banks and past quotes, and active, where the model is based on third party data (from other markets) and takes into account the liquidity and macroeconomic situation in the banking sector. The latter is the target model, although adjusting will take time and is likely to be stopped by a fundamental change in benchmark calculation. In the long run, pursuant to the regulations, only benchmarks based on transactions made will be able to receive a regulator's licence and remain in the market. The advantage of transactional benchmarks will also result from the preferences of the panellists and benchmark users. The panellists will avoid, at any cost, participation in panels based on expert judgment and the users will try to use benchmarks that are highly representative and resistant to manipulation.

The implementation of a new transparent benchmark calculation methods will certainly make benchmarks more robust, transparent and resilient. The reform generates, however, a legal risk connected with benchmark conversion and the stability of contracts based on the existing benchmarks. Therefore the changes must be carefully monitored by all stakeholders: regulators, supervisors, administrators, banks and final benchmark users.

\section{Bibliography}

Abrantes-Metz R., Kraten M., Metz A., Seow G., 2012, Libor manipulation?, Journal of Banking \& Finance, vol. 36, no. 1, pp. 136-150.

ACI Polska, 2013, Regulamin fixingu stawek referencyjnych WIBOR $i$ WIBID, 1.07.2013. 
Avery C., Zemsky P., 1998, Multidimensional uncertainty and herd behavior in financial markets, American Economic Review, 88 (4/September), pp. 724-748

BIS, 2013, Towards Better Reference Rates Practices: A Central Bank Perspective, Bank for International Settlements, March.

Brousseau V., Chailloux A., Durre A., 2013, Fixing the fixings: What road to a more representative money market benchmark?, IMF Working Paper, no. 13/131, May 29.

Duffie D., Stein J., 2015, Reforming LIBOR and other financial market benchmarks, Journal of Economic Perspectives, vol. 29, no. 2, Spring, pp. 191-212.

EBA/ESMA, 2013, ESMA-EBA Principles for Benchmark-Setting Processes in the EU, ESMA/ 2013/659, June 6.

EP, 2016, Regulation of the European Parliament and of the Council on Indices Used as Benchmarks in Financial Instruments and Financial Contracts, Brussels, 8.06.2016.

Flavell R., 2002, Swaps and Other Derivatives, Wiley \& Sons, London.

FSB, 2014, Reforming Major Interest Rate Benchmarks, Financial Stability Board report, July 22.

Gandhi P., Golez B., Jackwerth J.C., Plazzi A., 2015, Libor Manipulation: Cui Bono?, Finance Research Seminar, April.

GPWB, 2017, Regulamin stawek referencyjnych WIBID $i$ WIBOR, 30.11.2017.

Gradoń W., 2013, Propozycje zmian wyznaczania stóp rynku międzybankowego określajacych rzeczywista cene pieniadza, Studia Ekonomiczne, 173, pp. 81-94.

Hou D., Skeie D., 2014, LIBOR: Origins, Economics, Crisis, Scandal and Reform, Federal Reserve Bank of New York Staff Report, no. 667, March.

IBA, 2017, ICE Libor Output Statement, 3.03.2017.

IOSCO, 2013, Principles for Financial Benchmarks Final Report, OICU-IOSCO, FR 07/13, July.

Kirti D., 2017, What are reference rates for?, IMF Working Paper, WP/17/13, January.

Lynch A., 2000, Thought contagions in the stock market, The Journal of Psychology and Financial Markets, 1.1, pp. 10-23.

Maciaszczyk M., 2018, Znikający rynek stawek WIBOR. Efekt zmian regulacyjnych dla wyceny stóp rynku międzybankowego w Polsce, Bank i Kredyt, 3, pp. 217-252.

Mielus P., 2016, Dylematy reformy indeksów rynku finansowego, Gospodarka Narodowa, 4/2016, pp. 91-114.

Mielus P., 2017, Vicious circle of the benchmark reform, Bezpieczny Bank, vol. 69, no. 4, pp. 108-129.

Mielus P., 2018, Behavioural aspects of benchmark quotation - the WIBOR case, Acta Universitatis Lodziensis Folia Oeconomica, 3(335), pp. 189-205.

Mielus P., Mironczuk T., 2015, Structure of the cost of deposits in selected EU Countries, Bezpieczny Bank, no. 3(60), pp. 89-101.

MPG, 2014, Market Participants Group on Reforming Interest Rate Benchmarks, MPG Final Report, March.

Shiller R., 1995, Conversation, information, and herd behavior, American Economic Review, 85 (2), May, pp. 181-185.

Wheatley, 2012, The Wheatley Review of LIBOR: Final Report, HM Treasury, September. 


\section{Appendix}

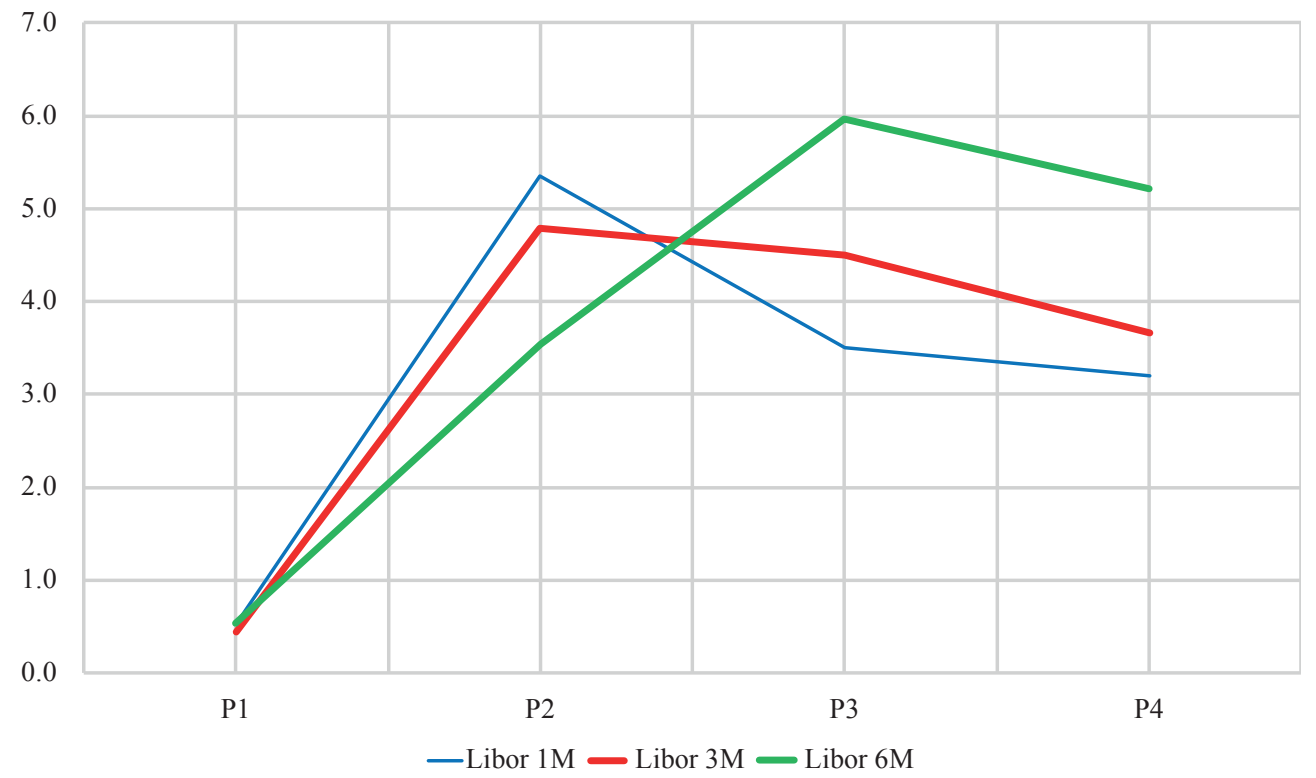

Fig. 1A. USD LIBOR interquartile range

Source: own elaboration based on TR data.

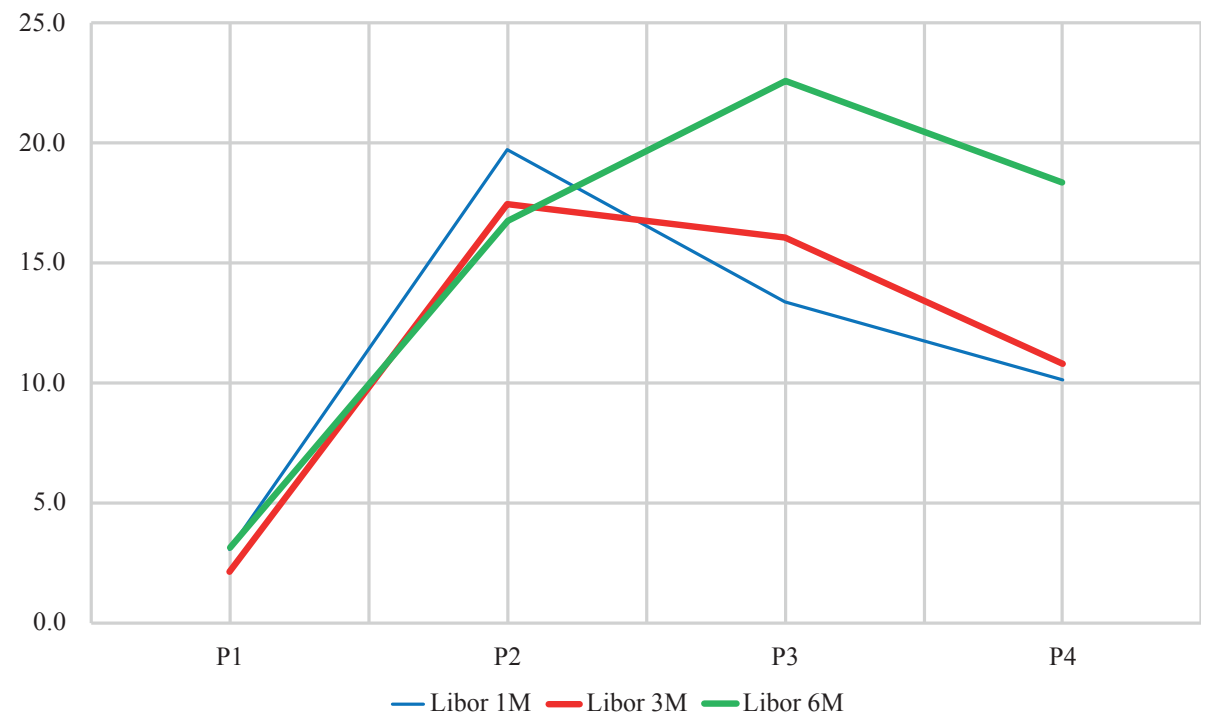

Fig. 2A. USD LIBOR min-max range

Source: own elaboration based on TR data. 


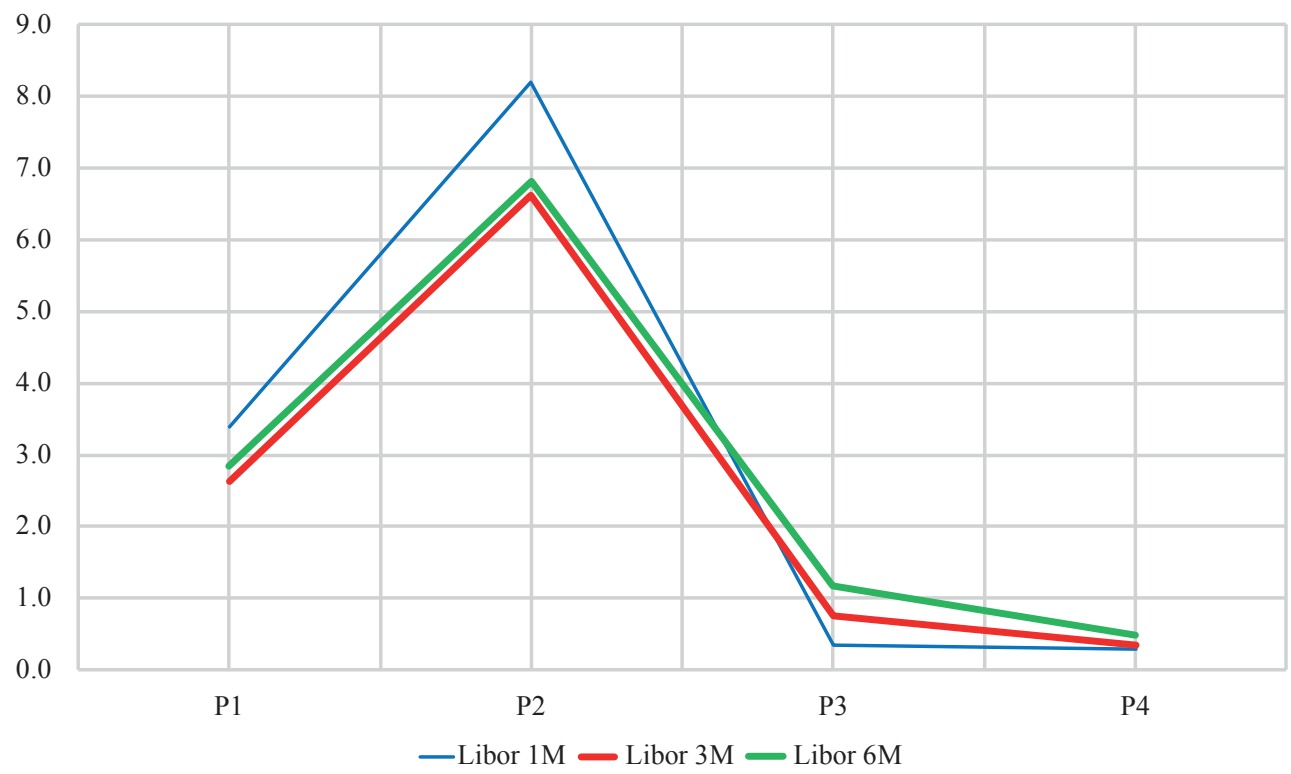

Fig. 3A. USD LIBOR daily standard deviation for fixing Source: own elaboration based on TR data.

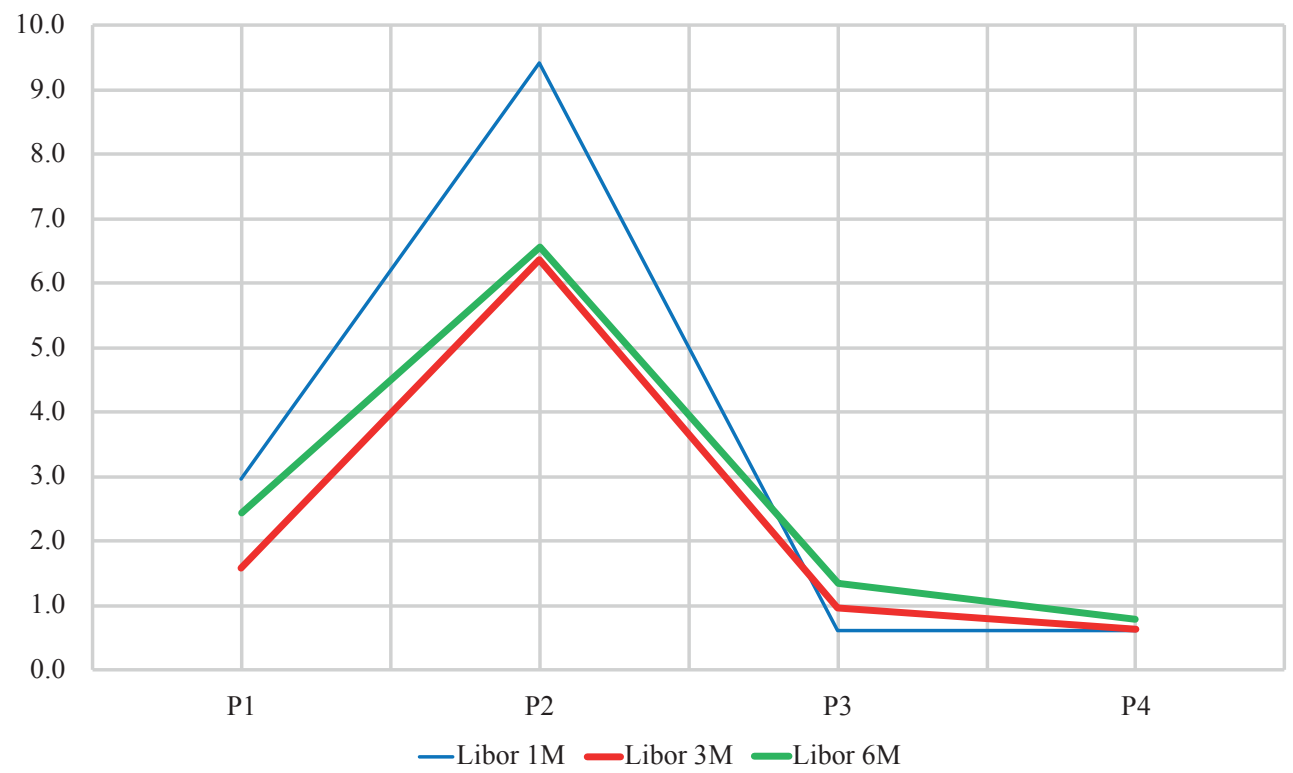

Fig. 4A. USD LIBOR average daily standard deviation for quotes Source: own elaboration based on TR data. 


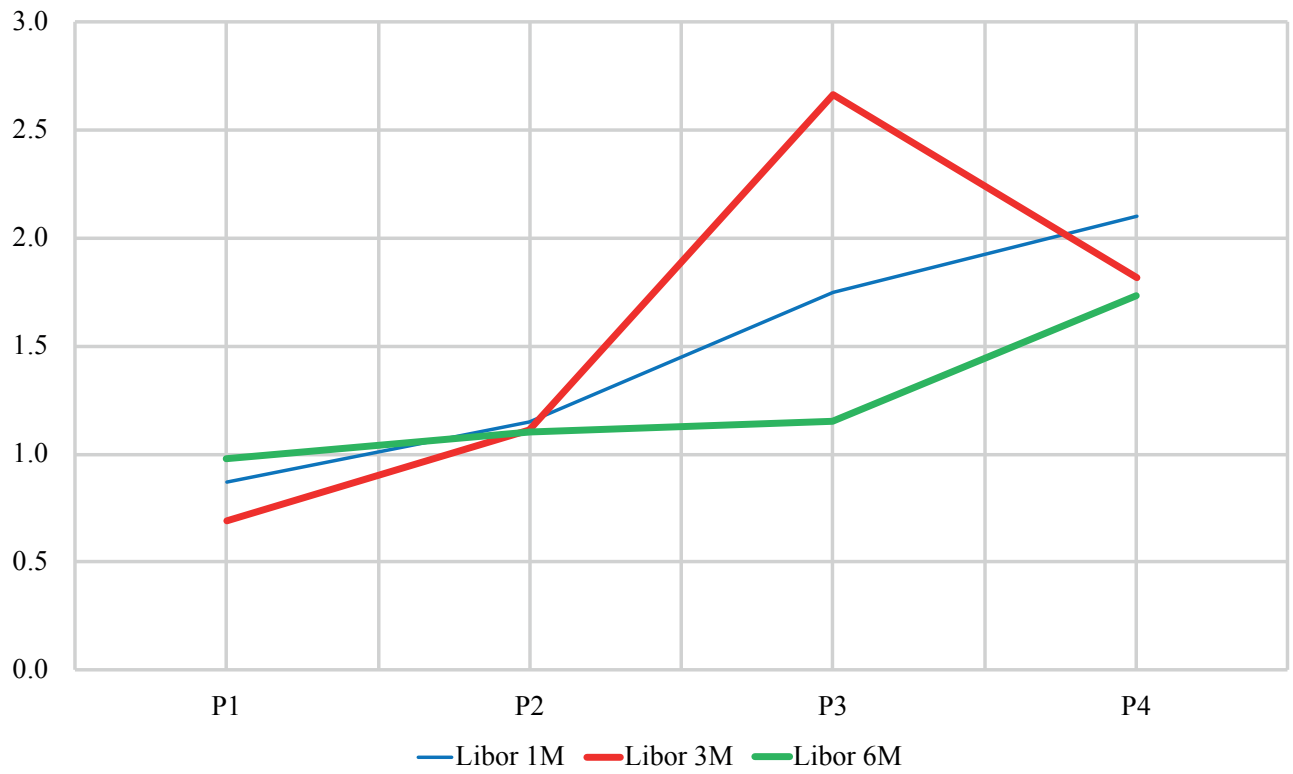

Fig. 5A. USD LIBOR average variance ratio

Source: own elaboration based on TR data.

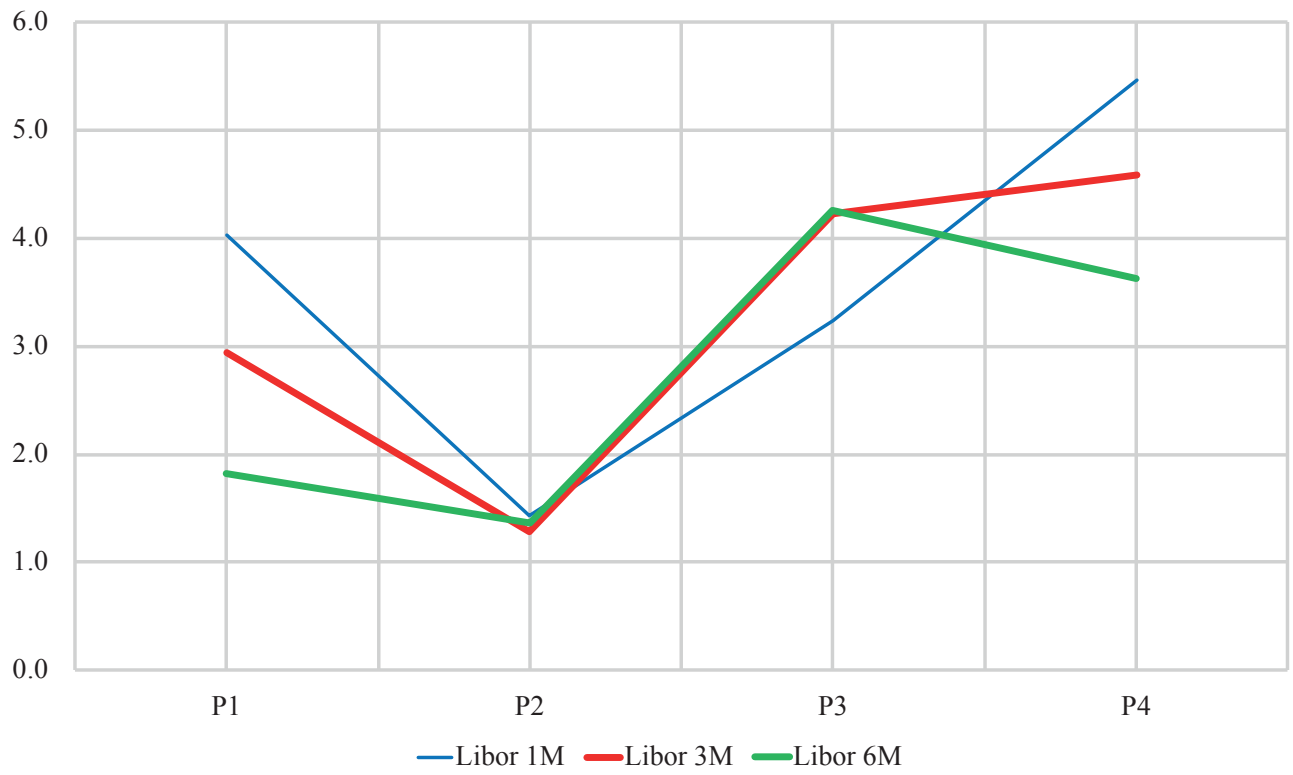

Fig. 6A. USD LIBOR quotient of max-min variance ratios

Source: own elaboration based on TR data. 


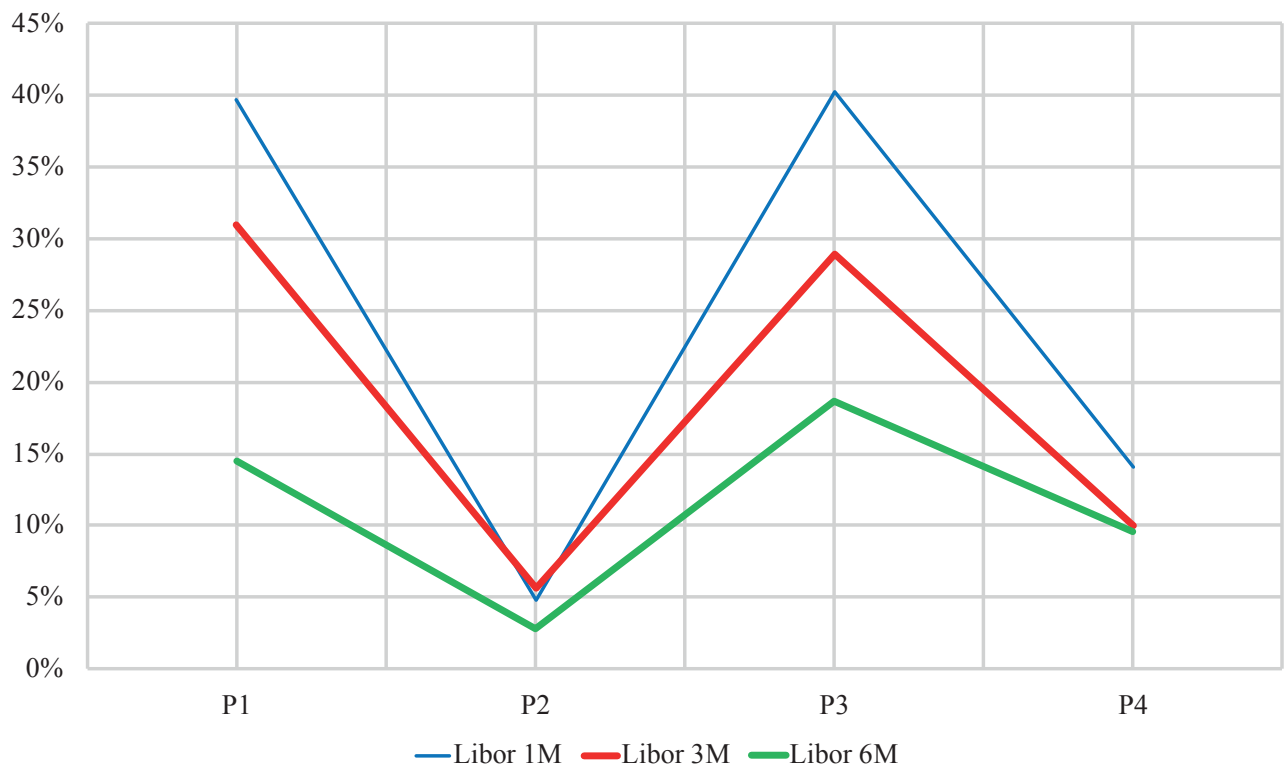

Fig. 7A. USD LIBOR share of zero changes for the index

Source: own elaboration based on TR data.

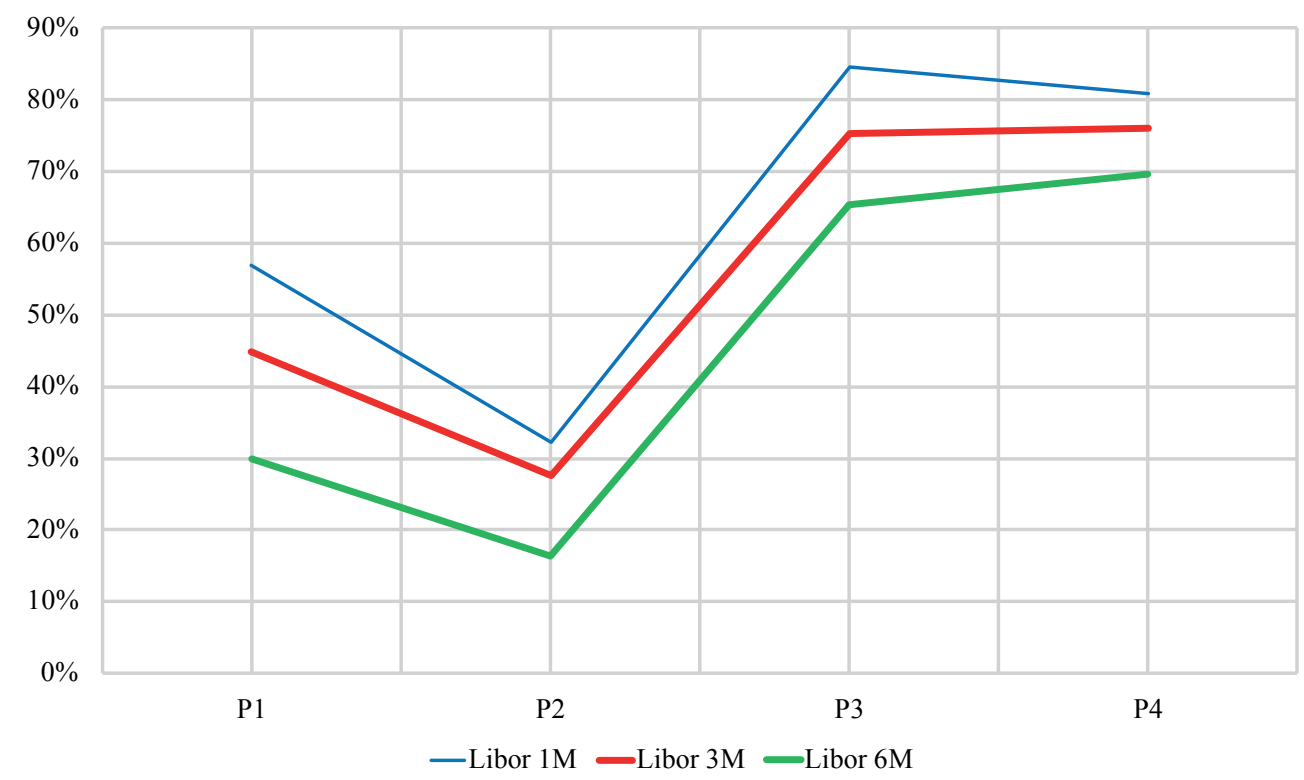

Fig. 8A. USD LIBOR average share of zero changes for the quotes

Source: own elaboration based on TR data. 


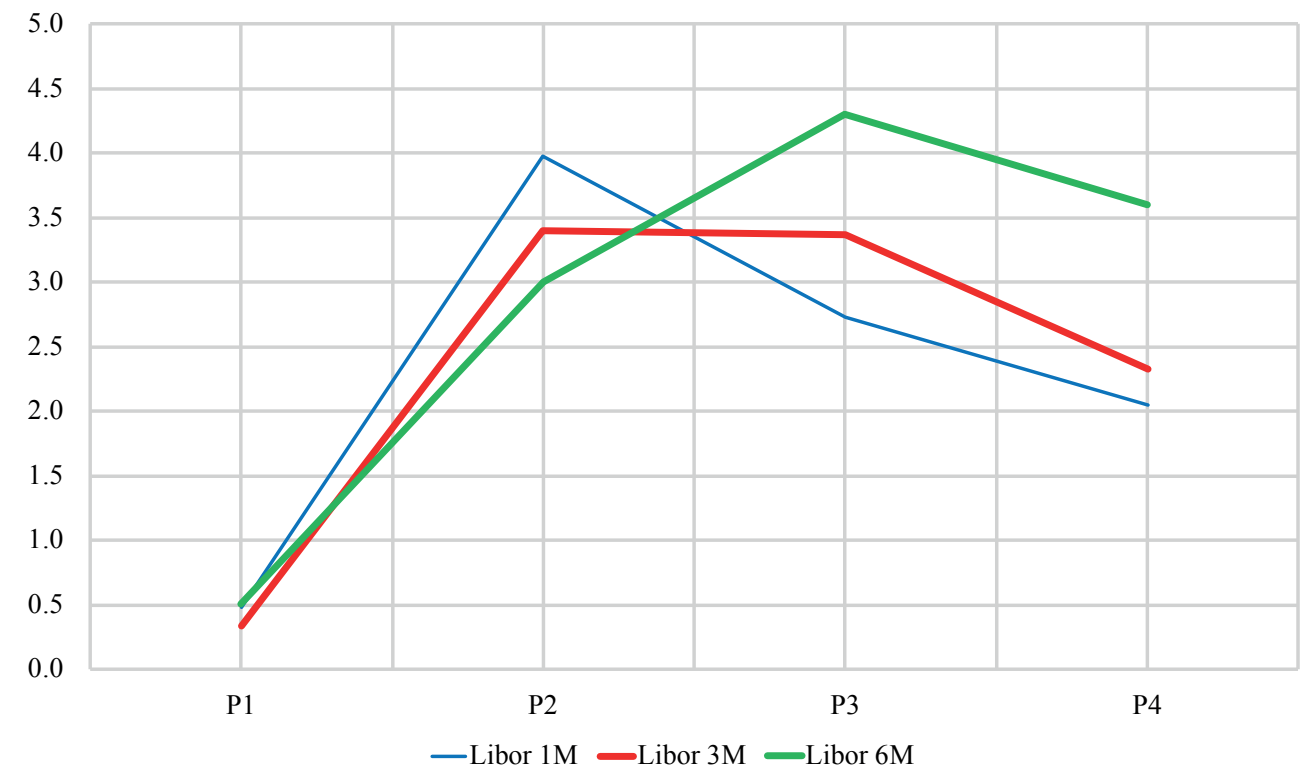

Fig. 9A. USD LIBOR average absolute error

Source: own elaboration based on TR data.

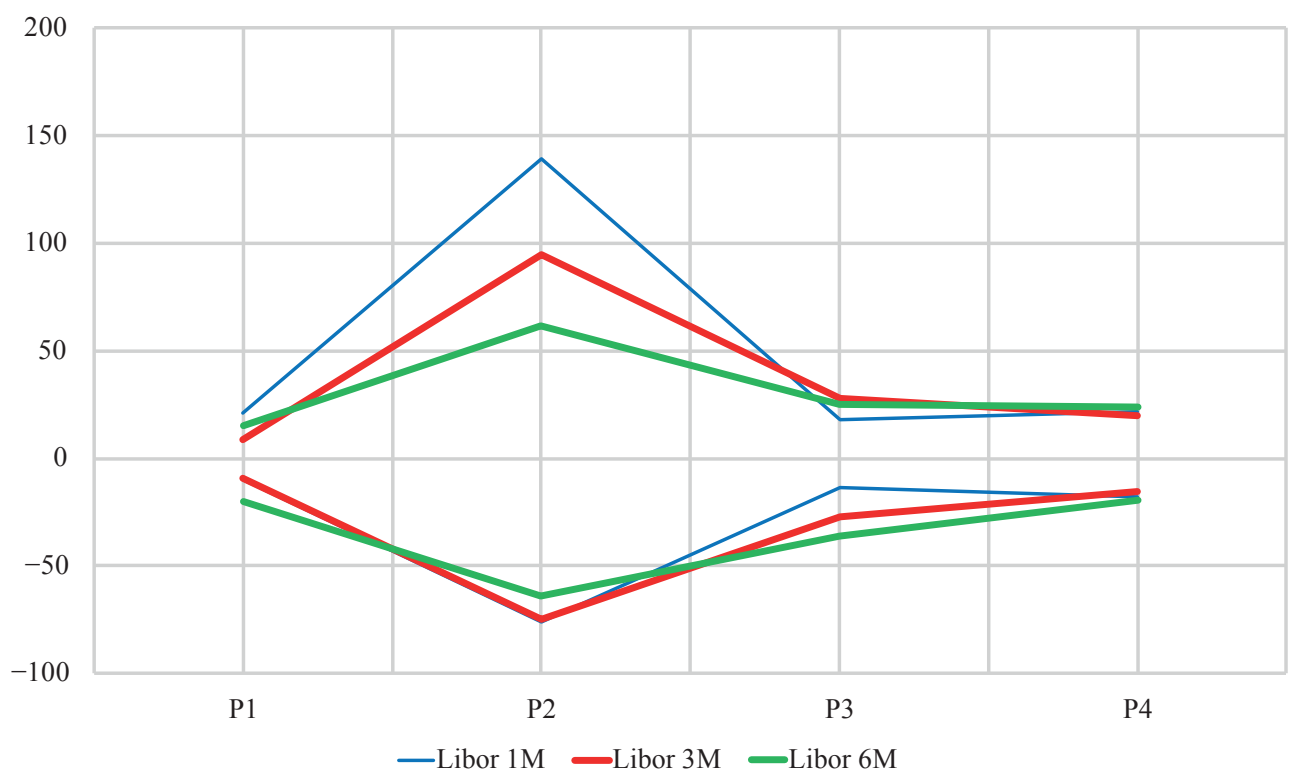

Fig. 10A. USD LIBOR average min-max error range

Source: own elaboration based on TR data. 


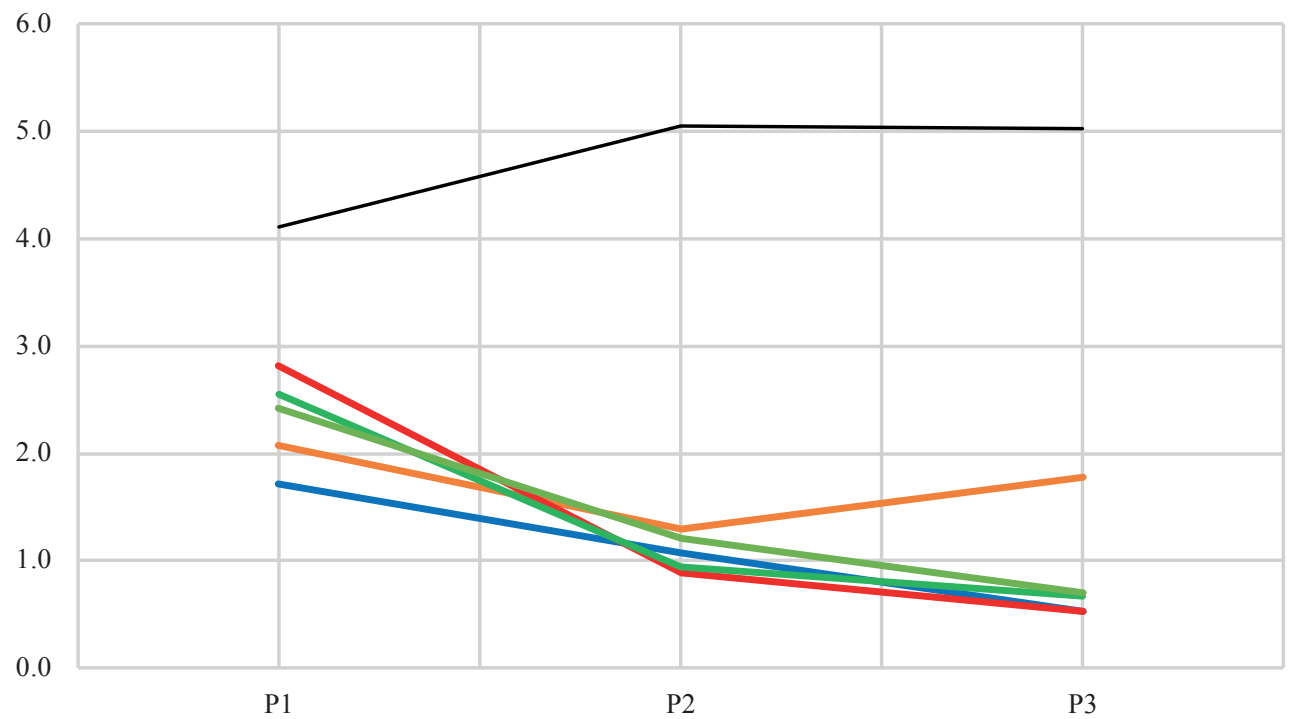

—Wibor ON - Wibor 1W -Wibor 1M -Wibor 3M -Wibor 6M -Wibor 1Y

Fig. 11A. PLN WIBOR interquartile range

Source: own elaboration based on TR data.

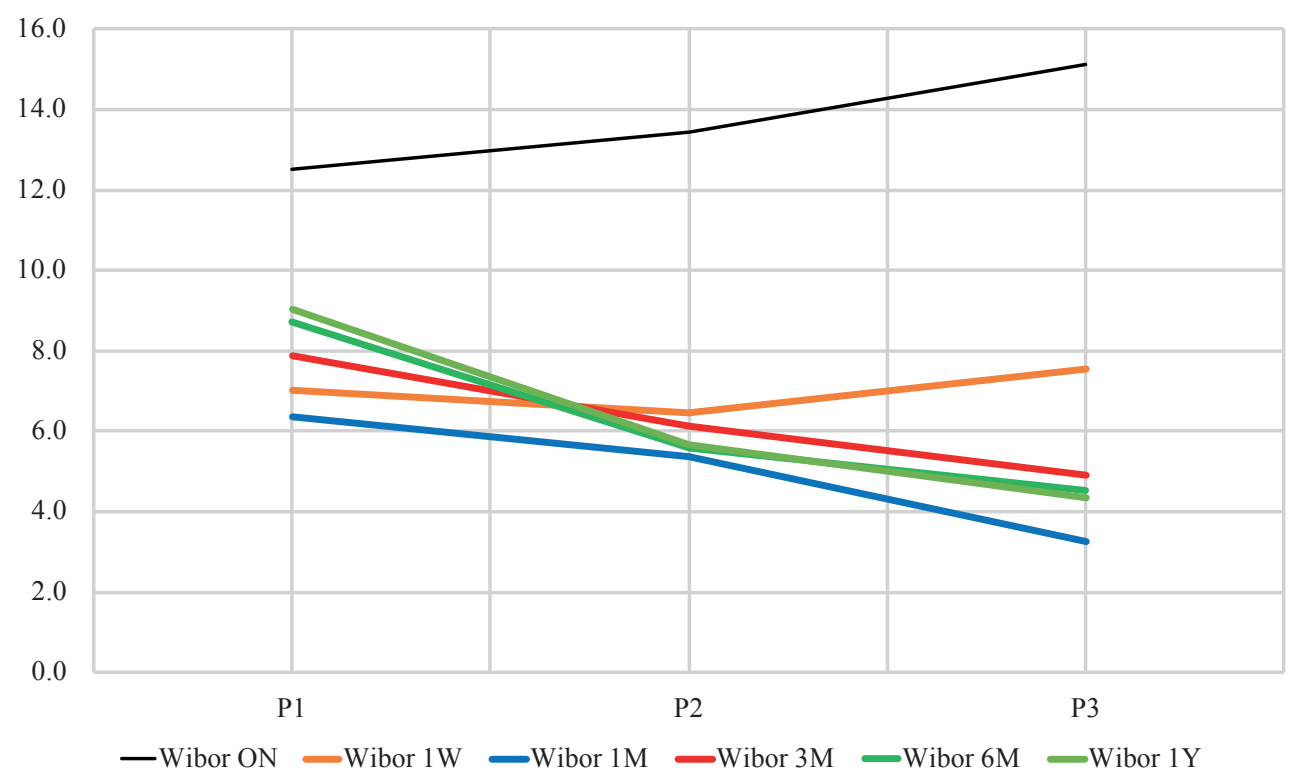

Fig. 12A. PLN WIBOR min-max range

Source: own elaboration based on TR data. 


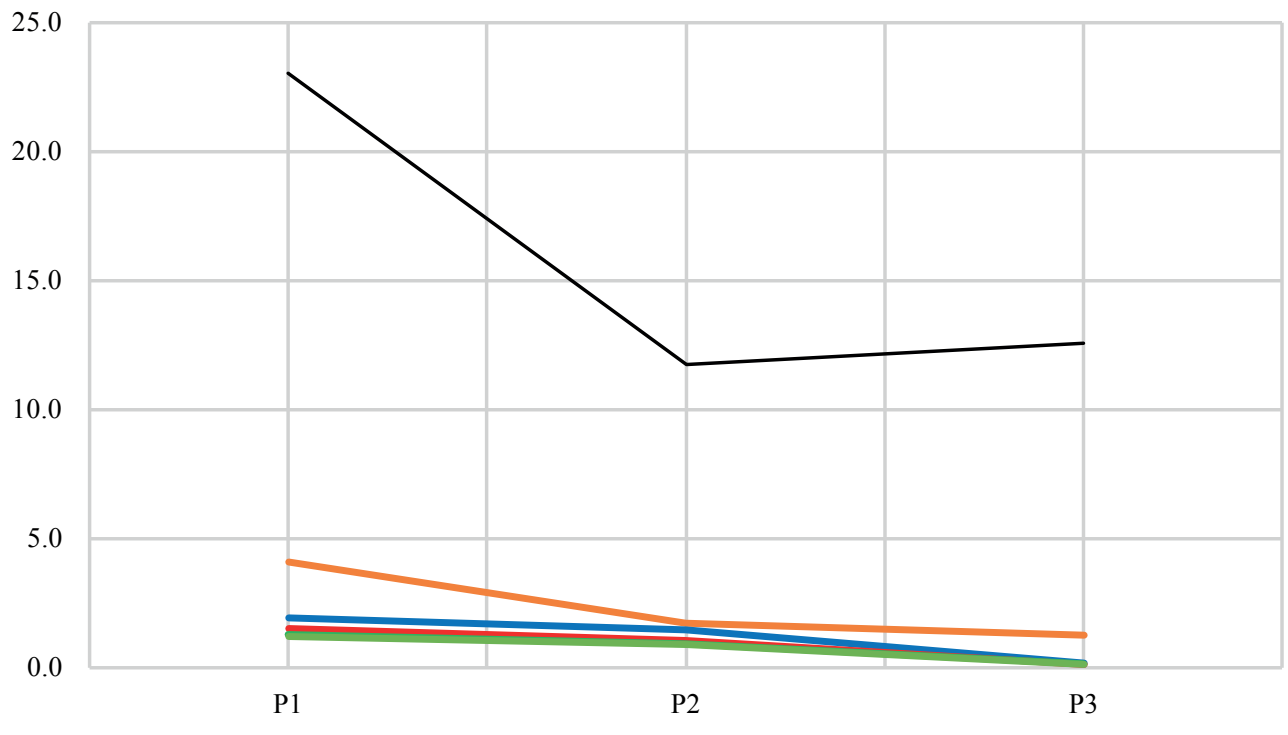

—Wibor ON - Wibor 1W - Wibor 1M -Wibor 3M —Wibor 6M -Wibor 1Y

Fig. 13A. PLN WIBOR daily standard deviation for fixing

Source: own elaboration based on TR data.

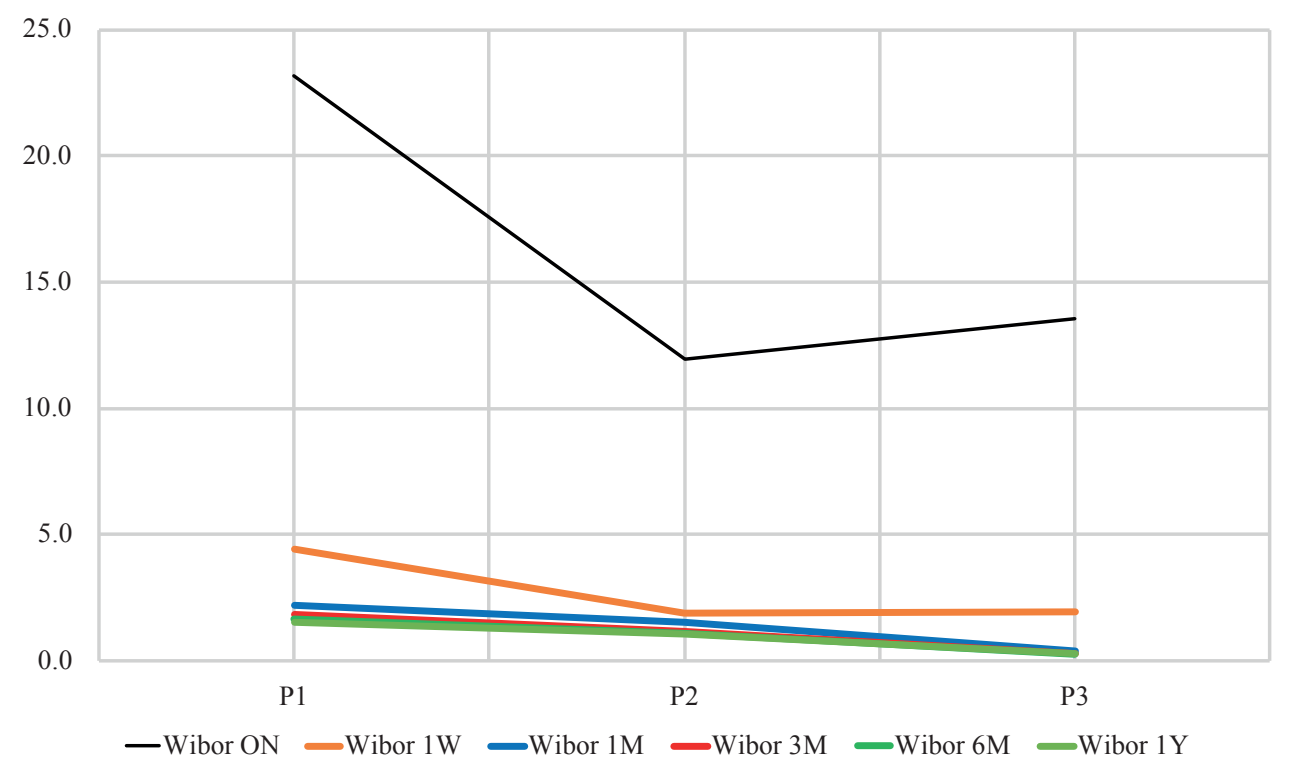

Fig. 14A. PLN WIBOR average daily standard deviation for quotes

Source: own elaboration based on TR data. 


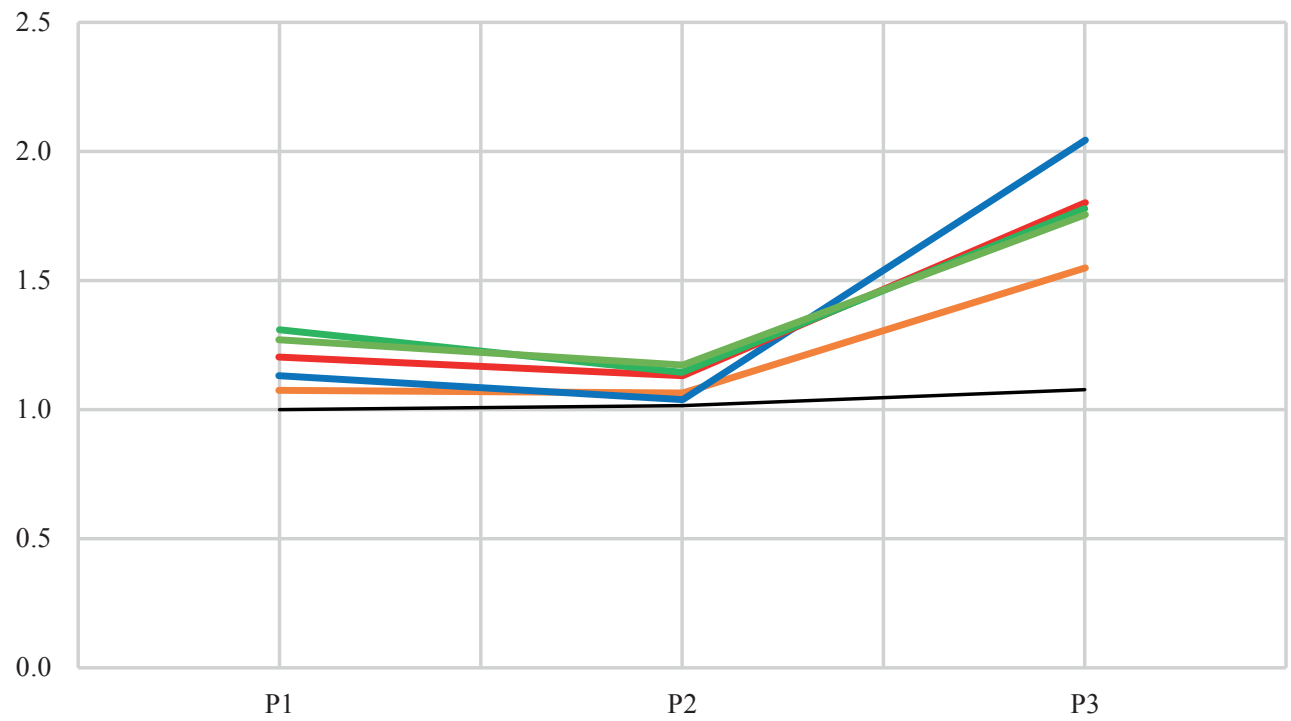

—Wibor ON —Wibor 1W -Wibor 1M -Wibor 3M -Wibor 6M -Wibor 1Y

Fig. 15A. PLN WIBOR average variance ratio

Source: own elaboration based on TR data.

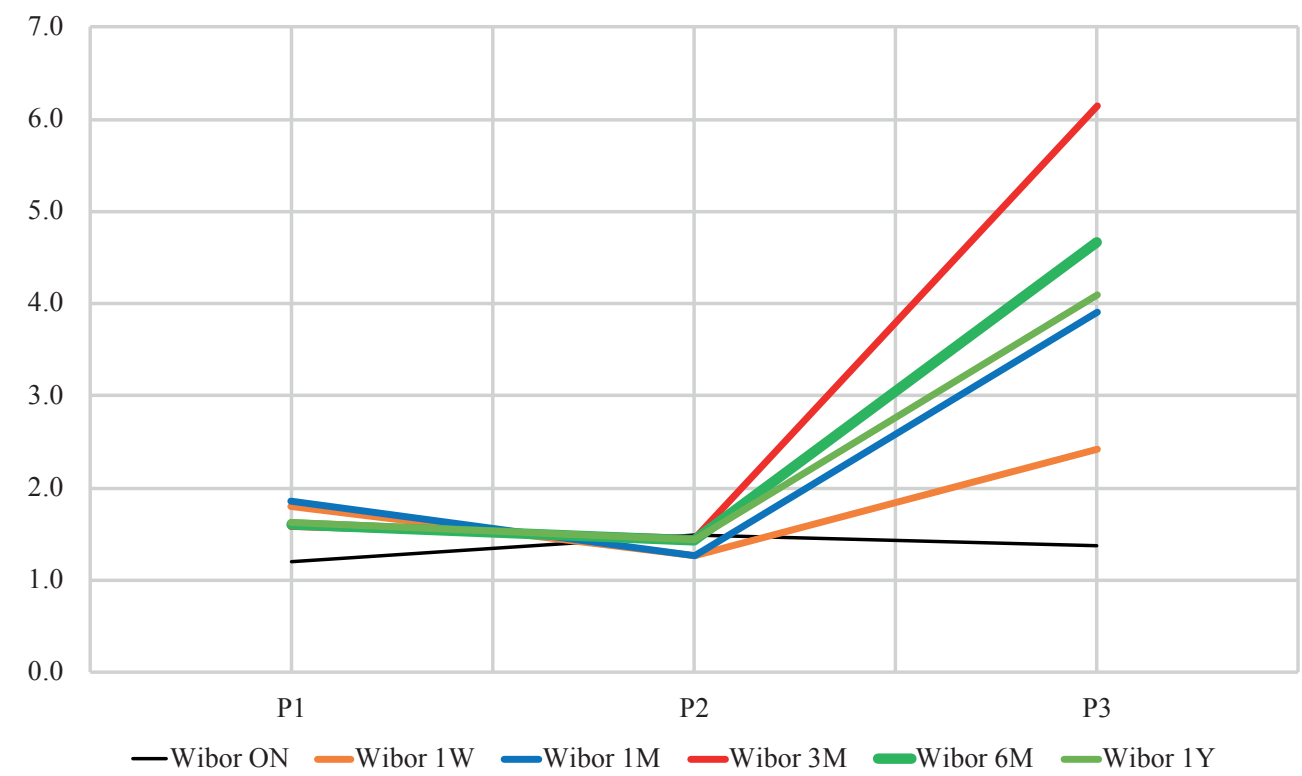

Fig. 16A. PLN WIBOR quotient of max-min variance ratios

Source: own elaboration based on TR data. 


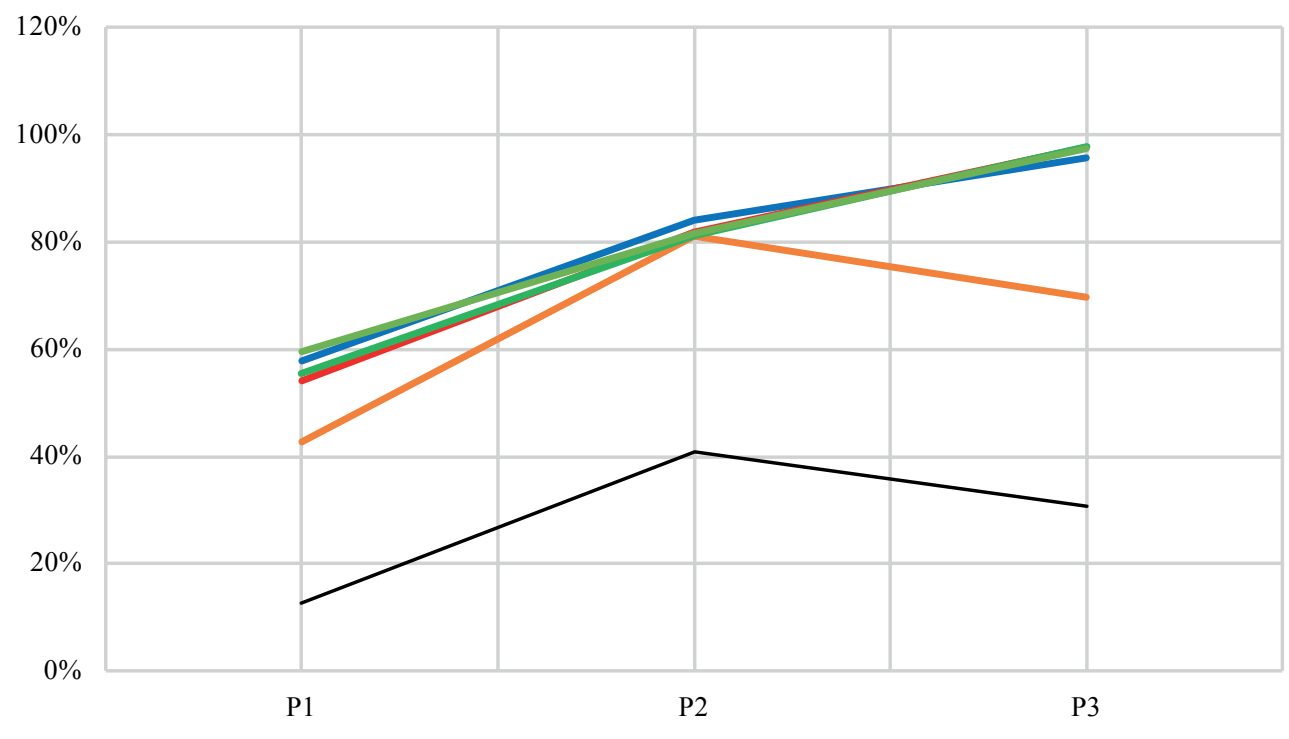

—Wibor ON - Wibor 1W -Wibor 1M -Wibor 3M -Wibor 6M -Wibor 1Y

Fig. 17A. PLN WIBOR share of zero changes for the index

Source: own elaboration based on TR data.

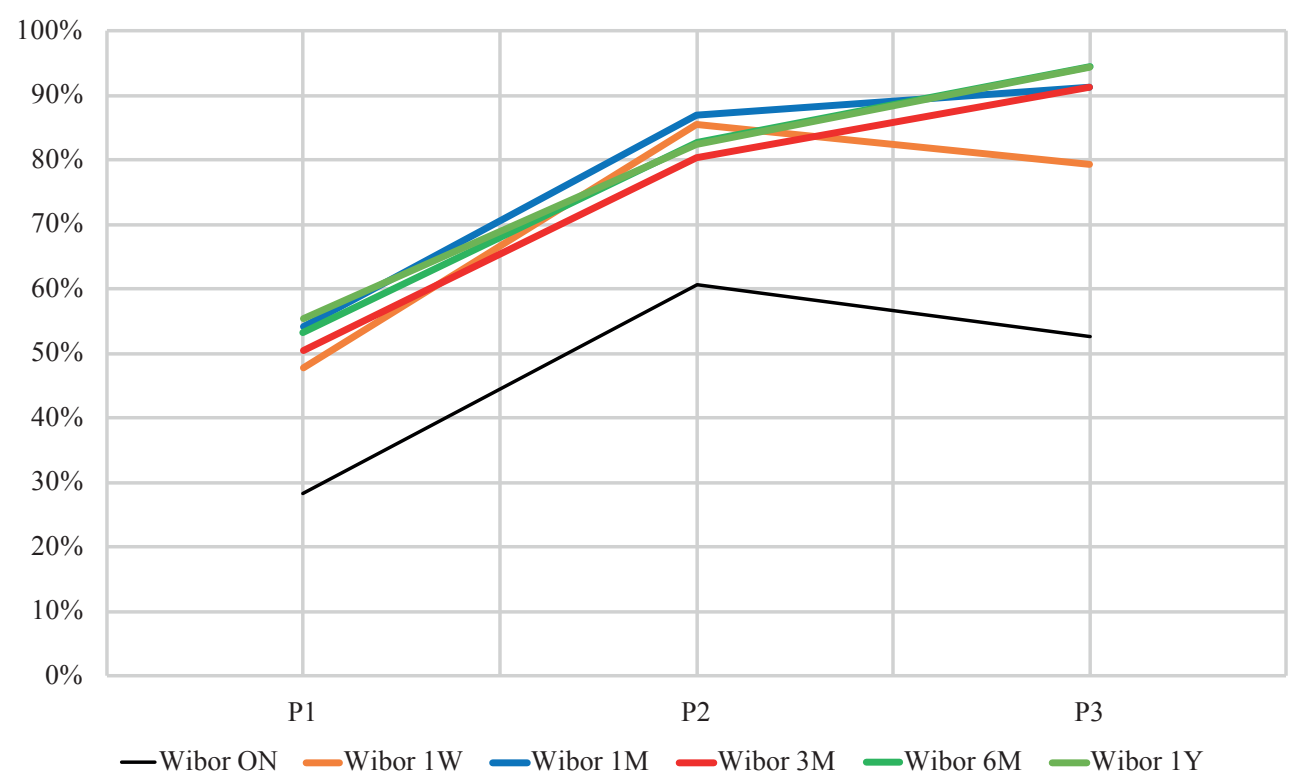

Fig. 18A. PLN WIBOR average share of zero changes for the quotes

Source: own elaboration based on TR data. 


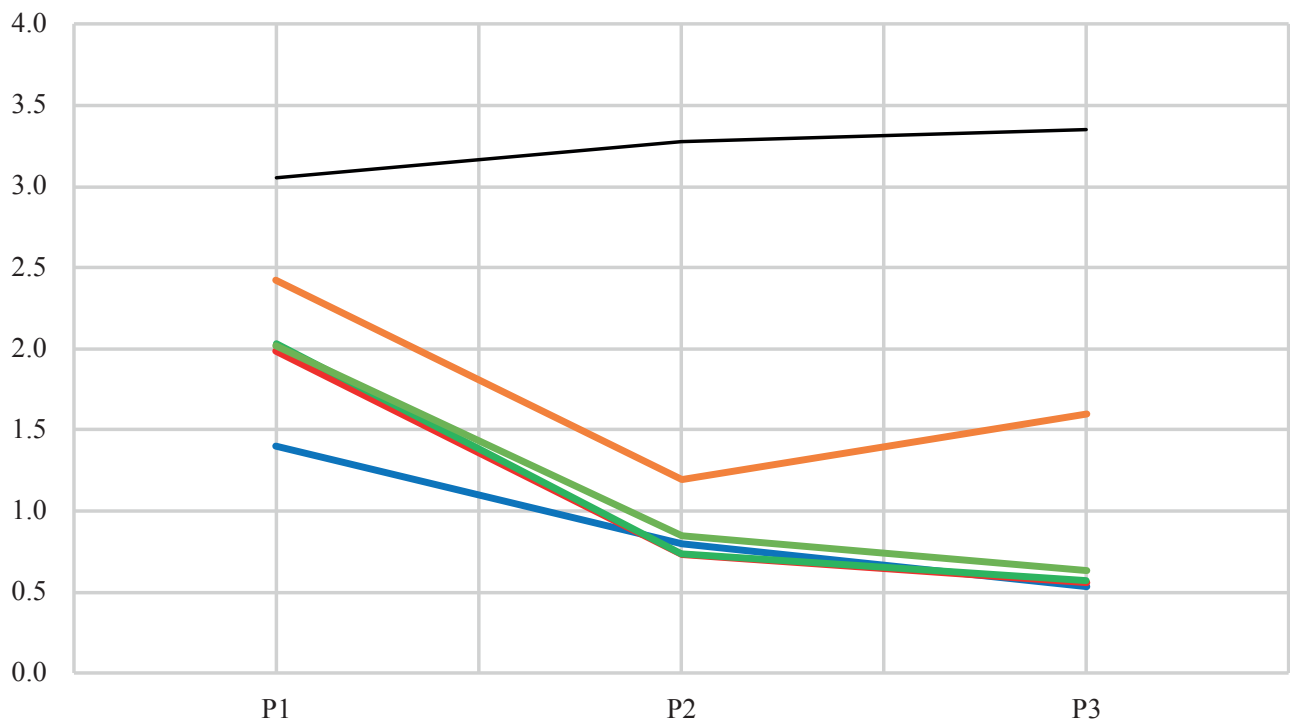

—Wibor ON —Wibor 1W -Wibor 1M -Wibor 3M -Wibor 6M -Wibor 1Y

Fig. 19A. PLN WIBOR average absolute error

Source: own elaboration based on TR data.

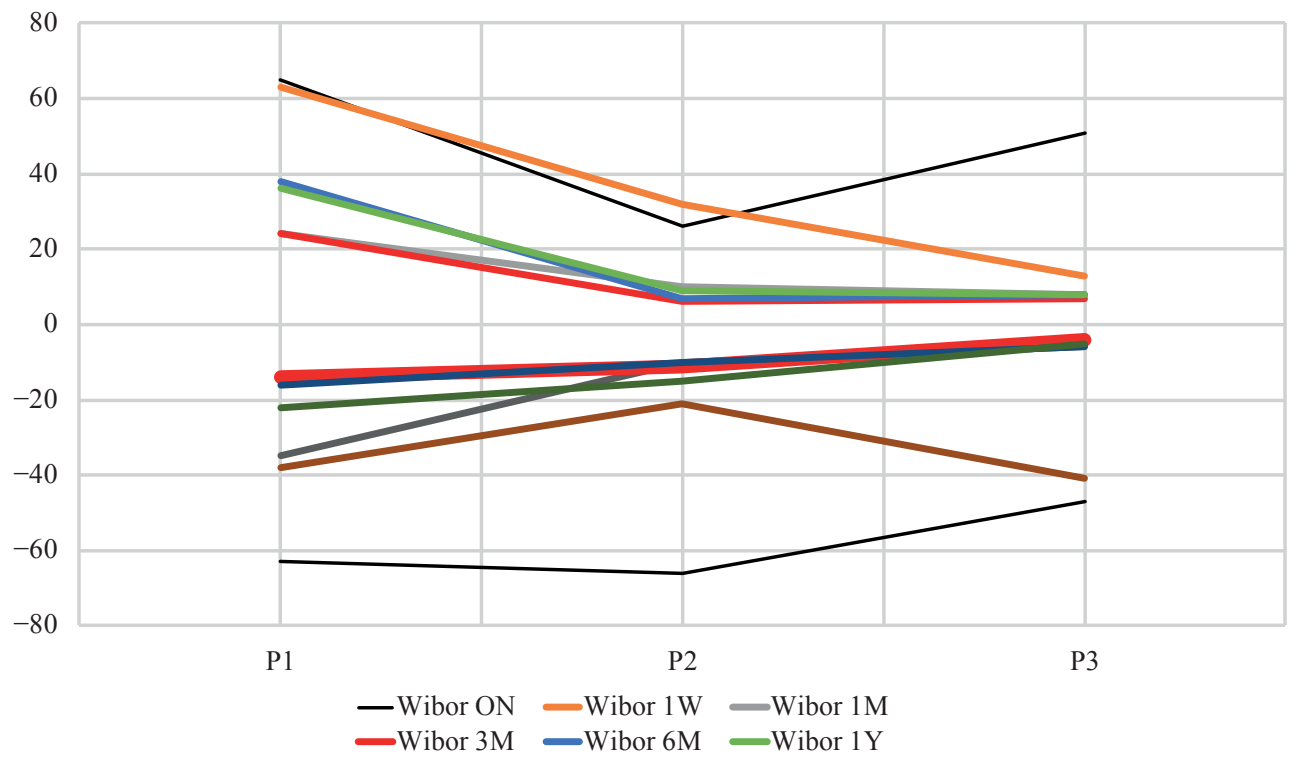

Fig. 20A. PLN WIBOR average min-max error range

Source: own elaboration based on TR data. 


\section{JAK MIERZYĆ EKONOMICZNĄ SPÓJNOŚĆ PANELI TYPU IBOR? PODEJŚCIE BEHAWIORALNE}

Streszczenie: Manipulacje stopami procentowymi typu IBOR zainicjowały wdrożenie nowych regulacji wymuszających reformę istniejących wskaźników rynku finansowego i wytworzenie nowych indeksów. Artykuł opisuje ewolucję dwóch panelów typu IBOR: globalnego indeksu LIBOR i lokalnego indeksu WIBOR. Prezentuję analizę ilościową kwotowań cząstkowych panelistów oraz sugeruje, jakie miary ekonomicznej spójności tych kwotowań powinny zostać wdrożone. Celem artykułu jest opracowanie wskaźników, które dostarczają informacji na temat efektywności procesu wytwarzania wskaźników stopy procentowej. Artykuł uzupełnia analiza behawioralna banków kwotujących stopy typu IBOR, co wpływa na finalny poziom i zmienność indeksu. Miary spójności będą pomocne nadzorcom w ocenie jakości przeszłych i teraźniejszych kwotowań stóp typu IBOR i umożliwią identyfikację czynników behawioralnych wpływających na kwotowania cząstkowe banków wchodzących w skład panelu IBOR.

Słowa kluczowe: wskaźniki rynku finansowego, rynek pieniężny, finanse behawioralne. 